\title{
Human meningitis due to Streptococcus suis in Lomé, Togo: a case report
}

Mireille Prince-David ${ }^{1,2}$, Mounerou Salou ${ }^{1,2}$, Corinne Marois-Créhan ${ }^{3,4}$, Komi Assogba $^{5}$, Céline Plainvert ${ }^{6,7}$, Koffi A. Balogou ${ }^{5}$, Claire Poyart ${ }^{6,7,8}$ and Asmaa Tazi ${ }^{6,7,8^{*}}$ (1)

\begin{abstract}
Background: Streptococcus suis is a zoonotic pathogen which represents the leading cause of meningitis in Southeast Asia and an emerging pathogen in the Western world, the main risk factor for infection being contact with pigs. In Africa, the prevalence of S. suis infections in swine and humans is largely unrecognized, with only one recent report of a limited case series.
\end{abstract}

Case presentation: We describe a human case of meningitis due to S. suis in a 32-year-old man living in Togo. The patient had no particular medical history and no risk factors for immunodeficiency but reported regular contact with pork products. Using specific immunological and molecular methods, we characterized the isolate as S. suis serotype 2, ST1, one the most prevalent and virulent clone worldwide. The outcome was favorable after one week of adapted antibiotic therapy but the patient was left with severe hearing disorders.

Conclusions: This work highlights the emergence of this pathogen in Africa and reinforces the need for accurate epidemiological and surveillance studies of $S$. suis infections and for educating clinicians and exposed groups in non-endemic countries.

Keywords: Case report, Streptococcus suis, Meningitis, Zoonosis, Neurologic sequelae, Capsular serotype

\section{Background}

Streptococcus suis is an emerging zoonotic pathogen in Europe, North-America and South-America [1, 2]. This encapsulated gram-positive coccus is responsible for meningitis, bacteremia, and pneumonia in swine and is mainly associated with meningitis and endocarditis in humans. Incidence is highly correlated to contact with pigs and eating of undercooked pork products, habits which are common in Southeast Asia where S. suis is endemic and represents the leading cause of meningitis in adults $[1,2]$. In the Western world, rates of $S$. suis infection are low and the vast majority of the cases involves highly-exposed groups such as abattoir workers and pig breeders [1]. Mortality rate reaches approx. $3 \%$ and neurologic sequelae in case of meningitis are frequent (60\%), making the global burden of S. suis infections in endemic countries

\footnotetext{
* Correspondence: asmaa.tazi@cch.aphp.fr

${ }^{6}$ Service de Bactériologie, Hôpitaux Universitaires Paris Centre, site Cochin, 75679 Paris cedex 14, France

${ }^{7}$ Centre National de Référence des Streptocoques, Hôpital Cochin, 75679

Paris cedex 14, France

Full list of author information is available at the end of the article
}

significant [2]. We report, according to the CARE guidelines, a human case of meningitis due to S. suis in Africa where the prevalence of this bacterium in swine and humans is largely unrecognized.

\section{Case presentation}

A 32-year-old man working as a carpenter in Lomé, Togo, was admitted in August 2015 to the University Hospital Campus of Lomé for a 3 day history of severe headaches, vomiting, fever, and intense agitation (Table 1). He had no particular medical history and no risk factors for immunodeficiency. At admission, the body temperature was of $36.4^{\circ} \mathrm{C}$, and the general state was acceptable, with a correct conservation of consciousness. The neurological examination did not show any sign of motor or sensitive defect, of cranial nerve dysfunction or cerebellar symptoms. There was no hearing or skin abnormalities, no obvious neck stiffness, and the rest of the clinical examination was normal. Acute meningeal hemorrhage was evocated as the initial diagnosis. Cranial computed tomography could not be performed and a symptomatic treatment associating antalgic, antipyretic, and anticonvulsant medication was 
Table 1 Case-patient timeline

\begin{tabular}{|c|c|c|c|c|c|}
\hline & Presenting concerns & Physical examination & Evaluations & Diagnosis & Interventions-Treatments \\
\hline Day of admission & $\begin{array}{l}\text { 32-year-old man, carpenter in Lomé } \\
\text { No particular medical history } \\
\text { 3-day history of headaches, } \\
\text { agitation, vomiting, fever }\end{array}$ & $\begin{array}{l}\text { Body temperature: } 36.4^{\circ} \mathrm{C} \\
\text { Neurological examination: normal } \\
\text { Clinical examination: normal }\end{array}$ & $\begin{array}{l}\text { Cranial computed } \\
\text { tomography: not performed }\end{array}$ & Acute meningeal hemorrhage & Symptomatic treatment \\
\hline Day 2 & $\begin{array}{l}\text { Persisting symptoms } \\
\text { Fever }\end{array}$ & $\begin{array}{l}\text { Neck stiffness Kernig and Brudzinski } \\
\text { signs positive }\end{array}$ & $\begin{array}{l}\text { Lumbar puncture: turbid } \mathrm{CSF}^{\mathrm{a}} \\
\text { CSF analysis: } \\
\text {-WBC } \mathrm{CH}^{\mathrm{a}}: 2,800 / \mathrm{mm} 3 \\
\text { (65\% lymphocytes,35 \% neutrophils) } \\
\text { - Protein: } 1.8 \mathrm{~g} / \mathrm{L} \\
\text { - Glucose: } 0.47 \mathrm{~g} / \mathrm{L} \\
\text { (plasma } 1.41 \mathrm{~g} / \mathrm{L} ; \text { ratio }=0.33 \text { ) } \\
\text { - Gram stain: negative }\end{array}$ & Bacterial meningitis & $\begin{array}{l}\text { Wide-spectrum } \\
\text { antibiotic therapy: } \\
\text { ceftriaxone, } \\
\text { ofloxacin, } \\
\text { metronidazole }\end{array}$ \\
\hline Day 3 & $\begin{array}{l}\text { Vertigo } \\
\text { Tinnitus }\end{array}$ & & $\begin{array}{l}\text { CSF culture positive: } \\
\text { catalase negative, gram-positive } \\
\text { cocci in chains }\end{array}$ & & $\begin{array}{l}\text { Adapted antibiotic therapy: } \\
\text { ampicillin, gentamicin } \\
\text { Corticoid therapy }\end{array}$ \\
\hline Day 4 & $\begin{array}{l}\text { Patient reported working as a } \\
\text { pork butcher every weekend }\end{array}$ & & $\begin{array}{l}\text { Bacterial identification: Streptococcus suis } \\
\text { Audiogram: severe hearing loss in I } \\
\text { eft and right ears ( } 80 \mathrm{~dB})\end{array}$ & $\begin{array}{l}\text { Bacterial meningitis due to } S \text {. suis } \\
\text { with neurological complications }\end{array}$ & \\
\hline Month 9 & Tinnitus & & $\begin{array}{l}\text { Audiogram: severe hearing loss } \\
\text { in left and right ears }(80 \mathrm{~dB})\end{array}$ & $\begin{array}{l}\text { Neurological sequelae } \\
\text { of the meningitis }\end{array}$ & \\
\hline
\end{tabular}


initiated. At the second day of admission, the patient was febrile, agitated, and still suffered from severe headaches and vomiting. The neck had become stiff, and Kernig and Brudzinski signs were positive. The meningeal signs led to the realization of a lumbar puncture, which yielded a turbid cerebrospinal fluid (CSF) concluding to the diagnosis of bacterial meningitis. An empiric intravenous antibiotic treatment associating ceftriaxone $(2 \mathrm{~g}, 2 \times / \mathrm{d}$ for $24 \mathrm{~h}$ then $1 \mathrm{~g}, 2 \times / \mathrm{d})$, ofloxacin $(200 \mathrm{mg}, 3 \times / \mathrm{d})$, and metronidazole (500 mg, $2 \times / \mathrm{d}$ ) was started.

CSF analysis showed 2,800 leukocytes $/ \mathrm{mm}^{3}$ (65 \% lymphocytes and $35 \%$ neutrophils), a protein concentration of $1.8 \mathrm{~g} / \mathrm{L}$, and a glucose concentration of $0.47 \mathrm{~g} / \mathrm{L}$ $(2.6 \mathrm{mmol} / \mathrm{L})$ with a plasma glucose concentration of $1.41 \mathrm{~g} / \mathrm{L}(7.8 \mathrm{mmol} / \mathrm{L}$; ratio $=0.33)$. Gram staining did not reveal any microorganism. Blood and CSF cultures, after $48 \mathrm{~h}$ and $24 \mathrm{~h}$ of incubation, respectively, grew small beta-hemolytic colonies on horse blood agar plates. The bacteria were catalase negative, gram-positive cocci, in chains or in pairs. They were identified as S. suis (score 2.56) by MALDI-TOF (Matrix Assisted Laser Desorption Ionisation Time Of Flight) spectrometry (BrukerTM) and as $S$. suis serotype 1 (97 \% probability) by VITEK 2 Grampositive card system (bioMérieux, Marcy l'Etoile, France). Slide agglutination with type-specific hyperimmune serum and specific multiplex PCR identified the isolate as $S$. suis serotype 2 , indicating a serotype misidentification by the automated card system, and concluding, together with MultiLocus Sequence Typing [3-5], to an infection due to S. suis serotype 2, Sequence-Type (ST) 1 , one of the most virulent and frequently isolated clone all over the world $[1,6]$. Antimicrobial drug-susceptibility testing performed according to the European Committee on Antimicrobial Susceptibility Testing (EUCAST) recommendations characterized the strain as susceptible to penicillin (Minimum inhibitory concentration $(\mathrm{MIC})<=0.25 \mathrm{mg} / \mathrm{L}$ ), erythromycin, clindamycin, levofloxacin, and linezolid and resistant to tetracycline.

After S. suis was identified, the patient reported working as a pork butcher every week-end. The patient did not have any sign or symptoms of endocarditis, and the antibiotic treatment was replaced by ampicillin $(2 \mathrm{~g}, 3 \times 1$ d) and gentamicin $(80 \mathrm{mg}, 2 \times / \mathrm{d})$ for 7 days. While the patient was receiving treatment for 1 day, vertigo and tinnitus developed, for which he received adjunctive corticoid therapy and the treatment was completed with no particular adverse events. Hearing disorders, especially hearing loss, are the most common sequelae of $S$. suis infections and affect more than $50 \%$ of patients who survive meningitis [2]. In that case, hearing disorders evolved into severe hearing loss in the left and right ears $(80 \mathrm{~dB})$, and the patient was still suffering from tinnitus 9 months after the diagnosis. One year later, tinnitus had disappeared and the patient's auditory function had improved from severe to moderate hearing loss.

\section{Conclusions}

Data for circulation and epidemiology of S. suis in Africa remain extremely scarce. This is the second report of a human S. suis meningitis in Togo, which, together with a recently published limited case-series [7], highlights the emergence of this zoonotic pathogen in Africa. Nevertheless, swine industry and pork products consumption, although extremely low compared to other continents, are steadily increasing [8], which might lead to a significant rise of S. suis infections in the future. Besides, S. suis infections are not limited to adult cases but also affect children [7], and specific attention should be paid to this other potential high-risk group. This case-report, for which clinical data, microbiological findings, and outcome were similar to those reported elsewhere $[1,2]$, emphasizes the need for educating both clinicians and exposed groups about $S$. suis infections and their severity in non-endemic countries. Particularly, accurate epidemiological and surveillance studies appear essential to assess the global burden of $S$. suis infections in swine and humans in Africa.

\section{Abbreviation}

CSF: Cerebrospinal fluid

\section{Acknowledgements}

Not applicable.

\section{Funding}

This work was not supported by any specific funding.

\section{Availability of data and materials}

The datasets used and analysed during the current study are available from the corresponding author on reasonable request.

\section{Authors' contributions}

MPD and MS analyzed the patient's microbiological data. CMC, CPI, CPo and AT performed and analyzed the molecular characterization of the bacterial isolate. $K A$ and $K A B$ analysed and interpreted the patient data regarding the neurological disease. MS, KA and AT were major contributors in writing the manuscript. All authors reviewed and approved the final manuscript.

Competing interests

The authors declare that they have no competing interests.

\section{Consent for publication}

The case-patient gave his written consent to publish.

\section{Ethics approval and consent to participate} Not applicable.

\footnotetext{
Author details

Centre de Biologie Moléculaire et d'Immunologie, Université de Lomé, BP 101, Lomé, Togo. ${ }^{2}$ Service de Microbiologie, Centre Hospitalier Universitaire Sylvanus Olympio, Tokoin Hôpital, BP 57, Lomé, Togo. ${ }^{3}$ Agence nationale de sécurité sanitaire de l'alimentation, de l'environnement et du travail, 22440 Ploufragan, France. ${ }^{4}$ Université Bretagne Loire, 22440 Ploufragan, France. ${ }^{5}$ Service de Neurologie, Centre Hospitalier Universitaire Campus, BP 30284, Lomé, Togo. ${ }^{6}$ Service de Bactériologie, Hôpitaux Universitaires Paris Centre, site Cochin, 75679 Paris cedex 14, France. ${ }^{7}$ Centre National de Référence des Streptocoques, Hôpital Cochin, 75679 Paris cedex 14, France. ${ }^{8}$ Université Paris Descartes, 75006 Paris, France.
}

Received: 24 August 2016 Accepted: 29 October 2016 Published online: 08 November 2016 
References

1. Huong VTL, Ha N, Huy NT, Horby P, Nghia HDT, Thiem VD, et al.

Epidemiology, Clinical Manifestations, and Outcomes of Streptococcus suis Infection in Humans. Emerg Infect Dis. 2014;20:1105-14.

2. Van Samkar A, Brouwer MC, Schultsz C, Van der Ende A, Van de Beek D. Streptococcus suis Meningitis: A Systematic Review and Meta-analysis. PLoS Negl Trop Dis. 2015;9:e0004191.

3. Marois C, Bougeard S, Gottschalk M, Kobisch M. Multiplex PCR assay for detection of Streptococcus suis species and serotypes 2 and 1/2 in tonsils of live and dead pigs. J Clin Microbiol. 2004;42:3169-75.

4. King SJ, Leigh JA, Heath PJ, Luque I, Tarradas C, Dowson CG, et al. Development of a multilocus sequence typing scheme for the pig pathogen Streptococcus suis: identification of virulent clones and potential capsular serotype exchange. J Clin Microbiol. 2002;40:3671-80.

5. Gottschalk M, Higgins R, Jacques M, Mittal KR, Henrichsen J. Description of 14 new capsular types of Streptococcus suis. J Clin Microbiol. 1989;27:2633-6.

6. Schultsz C, Jansen E, Keijzers W, Rothkamp A, Duim B, Wagenaar JA, et al. Differences in the population structure of invasive Streptococcus suis strains isolated from pigs and from humans in The Netherlands. PLOS ONE. 2012;7, e33854.

7. Tall H, Njanpop-Lafourcade B-M, Mounkoro D, Tidjani L, Agbenoko K, Alassani I, et al. Identification of Streptococcus suis Meningitis through Population-Based Surveillance, Togo, 2010-2014. Emerg Infect Dis. 2016;22:1262-4.

8. Food and Agriculture Organization of the United Nations, Statistics Division. http://faostat3.fao.org. Accessed 16 Aug 2016.

\section{Submit your next manuscript to BioMed Central and we will help you at every step:}

- We accept pre-submission inquiries

- Our selector tool helps you to find the most relevant journal

- We provide round the clock customer support

- Convenient online submission

- Thorough peer review

- Inclusion in PubMed and all major indexing services

- Maximum visibility for your research

Submit your manuscript at www.biomedcentral.com/submit

) Biomed Central 